\title{
Profecting Lives and Property in the Wildland-Urban Interface: Communities in Montana and Southern California Adopt Australian Paradigm
}

\author{
Robert W. Mutch*, Fire Management Applications, 9752 West Fork Road, \\ Darby, MT 59829, USA \\ Michael J. Rogers, Fire Management Consulting, 14646 Vintage Drive, \\ San Diego, CA 92129-3356, USA
}

Scott L. Stephens, Division of Ecosystem Science, Department of Environmental Science, Policy, and Management, University of California, 130 Mulford Hall, Berkeley, CA 94720-3114, USA

A. Malcolm Gill, Fenner School of Environment and Society, The Australian National University, Acton, ACT 0200, Australia; Bushfire Cooperative Research Centre, Albert Street, East Melbourne, VIC 3002, Australia

Received: 21 January 2010/Accepted: 17 July 2010

\begin{abstract}
Threats to people and property in the wildland-urban interface have taken on global proportions. It is becoming increasingly rare to have a wildland fire incident that does not involve people and their homes. In addition to Australia and North America, people have died in interface fires in Europe, Africa, and Asia, including 212 people who died in the devastating forest fires in northeastern China in May 1987. The prevailing interface model is one that attempts to evacuate people away from fire areas to get them out of harm's way. This traditional approach in the U.S. has been preferred by law enforcement agencies and fire services. The problem with this model is that evacuation warnings are often late to non-existent, leading to the deaths of interface residents entrapped by fires on highways as they try to escape. For example, 16 people suffered lethal burns when the 2003 Cedar and Paradise Fires in California overran them as they were trying to evacuate. Two communities in the United States have adopted variations of the Australian model of Prepare, Go Early, or Stay and Defend (P/GE/SD). Officials in the Painted Rocks Fire District, Montana, and Rancho Santa Fe, California, were interviewed to determine how the Australian model was being implemented. Two of the authors have firsthand experience with these two case examples. $\mathrm{P} / \mathrm{GE} / \mathrm{SD}$ has been tested successfully at both locations. The Australian model, however, is under review following the Black Saturday fires of February 2009 in Victoria, Australia. The objective of this paper is to present specific ideas that can be used to reform and improve fire policy, planning, and performance in the Wildland-Urban Interface in the United States.
\end{abstract}

\footnotetext{
* Correspondence should be addressed to: Robert W. Mutch, E-mail: bobmutch@montana.com
} 
Keywords: Fire evacuation, Fire safety, Forest fire, Home ignition zone, Prepare/Go Early/Stay and Defend, Wildfires, Wildland fires, Wildland-urban interface

\section{Introduction}

The wildland-urban interface (WUI) and wildland-urban intermix (WUI) are the areas where structures are built next to and among forests, shrublands, and grasslands [1]. The WUI poses a series of challenges to both rural and urban communities from ecosystem fragmentation, increased exposure to invasive species, water and air pollution, loss of wildlife habitat, and wildfire [2]. These challenges are exacerbated by the vulnerability of the WUI to rapid land-use change throughout the United States and Australia [3].

Addressing land management and conservation concerns in the complex and changing landscapes at the WUI requires the implementation of clear and effective policies. Such policies would integrate appropriate aspects of land use planning, land management, urban design, community education, and fire agency activities. Wildfire (or 'unplanned fire') is one of the most critical hazards facing these communities in the WUI. It is a highly variable and seasonal hazard providing the most extensive impact during infrequent extreme events [4]. The challenge is to appropriately address and manage this hazard to lifestyle and other values that communities in these areas hold.

In both the United States and Australia large numbers of home losses and many fatalities have occurred. The 'California Fire Siege' [5] in 2003 and the Black Saturday fires in Victoria, Australia [6] are recent examples. Responses to these events can include the boosting of suppression capacity, changed fuel management practices, and new building regulations. The threats to people and property in the interface have taken on global proportions. It is becoming increasingly rare to have a wildland fire incident that does not involve people and their homes [7]. In addition to Australia and the United States, people have died in interface fires in Mexico [8], Europe (e.g. [9]), Africa [10], and Asia, including 212 people who died in the devastating forest fires in northeastern China in May 1987 [11].

The 'wildland' (bush in Australia) side of the WUI may be grasslands, shrublands, and forests of various types [12]. Major societal losses may occur adjacent to each of these fuel types under certain circumstances. On the urban side of the WUI, similarly, the nature of the houses and landscaping can vary from mansions with manicured gardens to modest mobile homes in trailer parks with little space for gardens. A wide range of urban and wildland situations can be subject to intense wildfires with socially disastrous consequences [13].

Some efforts have been developed in the United States to promote the use of ignition resistant building materials, ember trapping ventilation systems, and creation of defensible space within $30 \mathrm{~m}$ of exterior walls in the WUI. The use of ignition resistant building materials has been shown to be of major importance regarding structure survival during wildfires in the United States [14] and Australia $[15,16]$. While these aspects are critically important in determining structural survival, few comprehensive laws or statutes exist in the United States addressing the threat of external ignitions on structures [3]. One of the reasons for this lack 
of regulation governing the private side of the WUI is the American spirit of individualism which resents government interference in closely guarded personal rights $[17,18]$.

The objective of this paper is to present specific ideas that could be used to reform and improve fire policy and planning in the WUI in the United States. To be achieved, substantive reform requires better development, dissemination, and utilization of scientifically based information [19]. The ensuing discussion will develop a conceptual agenda for this policy. We will discuss how two variations of the 2001 Australasian Fire Authorities Council (AFAC) policy (e.g. see [20, 21]) of Prepare, Go Early or Stay and Defend ( $\mathrm{P} / \mathrm{GE} / \mathrm{SD})$ are being applied in two communities in the United States to better safeguard life and property, and how the policy is unfolding in Australia. Information from this paper should be of interest to planners, managers, and policymakers working in or near the WUI; and to residents who live in the interface.

\section{Wildland-Urban Inferface in the United States}

Major fire-prone WUI areas are located along the west coast of the United States, the Colorado Front Range, Texas, and the northern Great Lakes States. The WUI is also common on the fringe of major metropolitan centers such as Los Angeles, Seattle, Denver, Dallas, Atlanta, Washington DC, New York, and Boston [22]. The area being converted to WUI continues to increase throughout the United States as people desiring a more rural lifestyle move into wildfire prone areas [22].

The environmental consequences of urban expansion, and thus the length of the WUI, are becoming increasingly evident. Former U.S. Forest Service Chief Dale Bosworth [23] identified land conversion to urban use as one of the four main threats to public and private forests in the United States. Public concern about the social and environmental impacts of the WUI has grown in recent years [24-26].

Throughout the western United States many key public concerns center on wildfires in the WUI. Wildfires pose a direct and obvious threat to lives and structures. The socio-economic consequences of escaped fires in the WUI far exceed those in wildland areas alone. As a result, policy makers and land managers have focused much attention on alleviating the threat of fire in the WUI. A continuing problem for land management agencies such as the U.S. Forest Service is the cost of providing fire suppression for the WUI. The Forest Service, whose focus is on the management of federal wildlands, has a mandate to expend suppression resources on wildland fires [27], not on structure protection.

Programs have been initiated throughout the United States to address fire problems in the WUI. These include zoning, growth boundaries, land acquisition, education, community assistance programs, and procurement of conservation easements. Debates currently exist in the United States over the specific types of fuel treatments that are most appropriate in relatively remote federal forests [28]. However, the consensus regarding fuel treatments in the WUI is that treatments 
should reduce surface, ladder, and canopy fuels, regardless of forest types (e.g. ponderosa pine (Pinus ponderosa Laws.), mixed conifer, lodgepole pine (Pinus contorta Loudon), (see [29]).

Several recent federal fire policies in the United States such as the National Fire Plan [30], the Collaborative Approach for Reducing Wildfire Risks to Communities and the Environment: Ten-Year Comprehensive Strategy (TYCS) [31], and the Healthy Forest Restoration Act [32] have specifically addressed fire management in the WUI. The HFRA specified that $50 \%$ of fuels treatments should take place in the WUI to reduce fuel (vegetation) levels. This has led to the creation of community-based efforts such as Firewise Communities ${ }^{\circledR}$ and Fire Safe Councils that are reducing fuel levels in the WUI using collaborative agreements [33].

Cova [34] concluded that many of our streets and freeways in the United States are already beyond carrying capacity and when an emergency evacuation is added to the situation, fleeing residents, in the case of wildfire, will be stuck in gridlock, thereby exposing evacuee's to being burned while sitting in their vehicles. His contention, just from the standpoint of traffic congestion during wildfire emergencies, is that residents can be much safer staying in their ignition resistant homes, if their homes and yards are indeed ignition resistant, and off the roads that are needed for emergency vehicle ingress and egress.

\section{Wildland-Urban Inferface in Australia}

The WUI in Australia involves many residents [35]. Not all fires can be quickly controlled under all weather conditions and at all locations (see [36]). Thus, not all houses can be protected under extreme circumstances. Under such extremes, especially, people may flee from fires but may find themselves in fatal situations as a result. Out of such incidents, the AFAC policy of leave early or stay with the house has arisen (see [20, 21]).

The AFAC policy, the $\mathrm{P} / \mathrm{GE} / \mathrm{SD}$ policy, encourages individuals to engage in risk assessment and fire planning processes so they can plan to either leave a fire prone area well before there is personal risk or to stay and defend their prepared property (see $[3,20,21]$ ). The Australian concept of $\mathrm{P} / \mathrm{GE} / \mathrm{SD}$ received wider acceptance following studies of the infamous Ash Wednesday fires that burned through parts of southeastern Australia in 1983 [20]. These studies showed: (1) that most homes were lost as the result of airborne embers both preceding the fire front and continuing well after the main fire front burned through and (2) that most civilians had died from radiant heat exposure while evacuating [20].

The $\mathrm{P} / \mathrm{GE} / \mathrm{SD}$ model, when appropriately employed, can turn local residents into positive assets rather than be potential liabilities [36, 37]. If an unplanned fire threatens an urban area, the residents may be asked to either make an informed decision to go early, or, stay and defend their prepared homes. Prepared means a continually maintained fire resistant home surrounded by a minimum of $30 \mathrm{~m}$ to $60 \mathrm{~m}$ of properly maintained fire resistant landscaping in the United States, called the home ignition zone [38]. A coordinated neighborhood approach may be 
needed in some places (see [4]). Going Early (GE) can even mean leaving properly maintained homes on extreme fire danger days and going to a safe location well before the report of any unplanned fires [21]. Residents are urged not to try and get out at the last minute because roads may be obstructed by fallen trees and smoke may obscure visibility [39], power-lines and power-poles may have fallen, and the road may cross the path of the fire.

Ideally, in this model, before the fire arrives able-bodied residents who decide to stay, after sending off children and elderly family members, will fill up buckets, pails, sinks, and bathtubs with water (alternate water supply for fire suppression in case residential water supply fails), close all doors and windows (to lessen the chance of ember entry), pull drapes away from windows (decrease chance of drapes igniting), pull furniture away from exterior walls, and fill roof gutters with water (to extinguish embers lodging there), for example. They may begin defending their homes (the D part of the model) from the barrage of airborne embers that can precede the main fire front. As the main fire front approaches, residents can retreat into their prepared homes while maintaining a careful watch on the behavior of the advancing fire front and checking for interior ignition, the Stay (S) part of the model. When the wind driven fire front passes by, usually within several minutes, able bodied, properly dressed, and aware residents again emerge from their homes with mops, buckets of water, and garden hoses, and continue the Defend (D) part of the model by extinguishing any glowing or flaming materials on the home or in their yards. They must continue these checks on their properties and, if able, their neighbors' properties, until the threat is abated. Guidelines are available from local or regional emergency services (e.g. [40]). The 2009 Black Saturday fires in Victoria, Australia [6], have resulted in a new fire risk category (catastrophic) that, if forecast, invokes a "leave the night before or early in the morning" recommendation, while the next two lower ratings come with the recommendation to "only stay if your home is well prepared, well constructed and you can actively defend it" [see www.cfa.vic.gov.au/residents/summer/fire dangerratings.htm for Victoria; accessed 18 May 2010].

It is critical to note that not all fires arrive with due warning. In many cases even those who planned to leave will have to use their house as a shelter rather than take the riskier option to flee in a vehicle or on foot. History, so far, has shown that late evacuation can be riskier than sheltering in place in these situations (see [20]). Haynes et al. [41] investigated the circumstances associated with 552 fatalities from Australian bushfires over the last 100 years or so (1900 to 2007-2008) and found that 32\% died as a result of "late evacuation", $26 \%$ died "defending property outside", $8 \%$ who died were "inside defendable property", $6 \%$ died "travelling through the area unaware", $16 \%$ died in unknown situations, and the remainder were in miscellaneous categories. A Royal Commission is deliberating on such matters in the light of the 173 deaths in 2009 in Victoria [6]. Thus, Teague et al. [6, p. 188] noted that two-thirds of the fatalities that occurred on Black Saturday occurred in homes. Why this is so has yet to be revealed but there are many possibilities concerning local fire, weather and fuel circumstances, preparedness of people, properties and neighborhoods, and decision making etc. Teague et al. [6, Chap. 7] set the scene. 
In New South Wales and, more recently, the Australian Capital Territory (ACT), Community Fire Units have been established and promoted. In the ACT, people in these units are trained, provided with personal protective equipment, and given access to public water mains to enable local-area wetting down of fuels

(

www.esa.act.gov.au/ESAWebsite/content_actfb/community_fire_units/

community_fire_units.html; accessed 18 May 2010). In Victoria, the Community Fire Guard program has an emphasis on understanding fire and being prepared for fire occurrence [37]. Such groups of volunteers in small communities and on the urban edge can complement the efforts of city fire brigades and volunteer and government rural brigades.

Of course, each fire-prone community has a wide demographic with varying perceptions of risk to their assets and their willingness to engage in risk mitigation strategies. The challenge is to provide the most accurate and detailed assessment of risk that each individual may face both from the likelihood that a fire event may occur and the vulnerability that the community member may have to this event $[25,42,43]$. There are also planning and building guidelines in Australia designed to provide minimum performance standards for structures in bushfire (wildfire) prone areas [44].

The Stay and Defend Strategy is based on the simple concept that "People Protect Houses and Houses Protect People" [20]. It is not the physical event (wildfire) that is a major problem in itself except in terms of how that event impacts the built environment and the social system [18]. It is not until the physical event starts to have a significant impact on things that humans value that efforts are made to either modify the hazard to their assets or reduce the impact of the hazard to their assets by changing human behavior [25].

Changing the fuel structure and quantity is an important option both on the property of a resident and in the urban and adjacent wildland environment, an option that poses certain social and scientific challenges [4]. Fire suppression as an option, while important, is outside the scope of our considerations here.

\section{Montana Fire District Unites Residents to be Part of the Solution}

The Painted Rocks Fire District in western Montana adopted, in the NorthernHemisphere Fall of 2006, the Australian interface strategy of $\mathrm{P} / \mathrm{GE} / \mathrm{SD}$, partly predicated on the lessons learned from the 2003 southern California Fire Siege described by Blackwell and Tuttle [5]. Mutch [45] described the event where fifteen Californian civilians received little to no evacuation warning that the fast spreading Cedar and Paradise wildfires were imminent threats to their neighborhoods on October 26, 2003. All fifteen people burned to death, most while attempting to escape, as they had no time to take proper precautions. One firefighter died a couple days later as he tried to save a home with his engine crew. Six other civilians, men between the ages of 54 and 93, died of heart attacks as they watched the Old Fire in San Bernardino County destroy their homes. The $23^{\text {rd }}$ person who died 
was a transient whose burned body was found in the path of the Cedar Fire in San Diego County. Officials in this western Montana Fire District decided that it was far better to prepare defensible property far in advance of a fire outbreak - and then go early or stay and defend property against the ember fires, depending on the inclination of the residents.

State law in Montana specifies that people cannot be forced to evacuate their homes when a fire occurs (Reference: MCA 10-3-104 (2), 10-3-406). Instead, they sign a waiver releasing local authorities of any responsibility should serious problems arise. Despite such a law, U.S. fire services and law enforcement personnel prefer to remove people from the fire area (in the belief that this is the safest action and, therefore, the lowest liability to fire managers) to get them out of the way of emergency responders. The removal of able-bodied residents can often be detrimental to structure survival and public safety.

In Montana, many neighbors in the West Fork of the Bitterroot River area refused to be evacuated by the Sheriff's Department when the Razor Fire threatened their homes in August 2000. The senior author of this paper was there. They banded together to protect the neighborhood, thinning trees to create survivable space, installing sprinkler systems, fighting fire, and providing local intelligence to incoming fire services. The integration of this neighborhood force with the fire services was recognized as an effective strategy in protecting homes and property. No lives or homes were lost in the area although high intensity crown fires and spot fires across fire lines were present. During the 2000 fire season there was not an authorized Fire Protection District in this area. One year later, residents who had been threatened by the previous year's wildfires approved the formation of the Painted Rocks Fire District based on a force of volunteer firefighters.

The Painted Rocks Fire District in this isolated Montana community along the West Fork of the Bitterroot River called their new interface protection policy "Prepare: Go Early or Stay and Defend" (P/GE/SD). This strategic title implies that every resident in the Fire District prepares their property in advance to be fire resistant, regardless of whether they are going to leave early or stay. This is perhaps the first retro-community in the U.S. to adopt this system, meaning that residents must now prepare their property to be defensible before they can safely stay. When wildfire threatens these Montana homes, able-bodied residents who prepared their homes may choose to shelter inside their homes when the fire front passes through and then emerge to protect their property.

The volunteer firefighters of the Painted Rocks Fire District work with their community residents to achieve Firewise ${ }^{\circledR}$ standards and show residents how to defend their homes (Figure 1). Through voluntary inspections and spring wildland fire training courses, local residents can create islands of safety for their homes and families and be prepared to stay and fight fires. Upon completing the spring two-day $\mathrm{P} / \mathrm{GE} / \mathrm{SD}$ training in 2008 , residents received a photo Identification Card that certified the training and allows the card holders passage through law enforcement roadblocks to get back to their homes when fires occur. Those who choose not to stay are encouraged to go early. Leaving late has resulted in more deaths than any other cause during major wildland fires in the United States and 


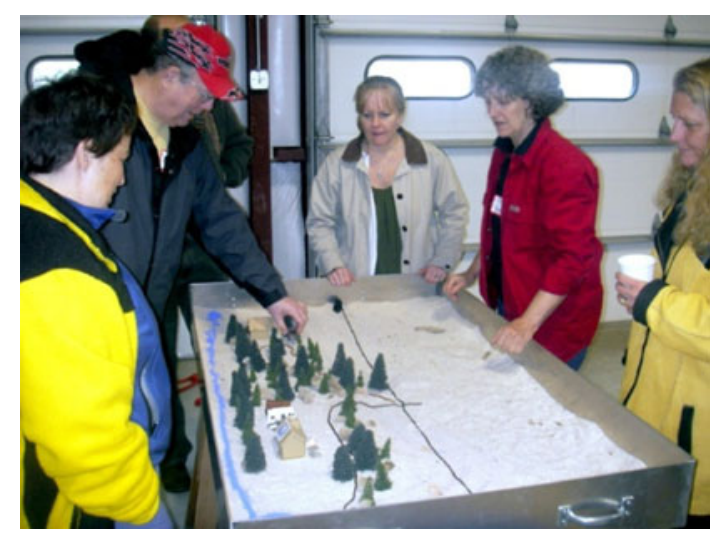

\section{Figure 1. District firefighter Erica Tresemer leads residents through a sand table exercise at the Painted Rocks Fire Station in June 2008 (Photo: Bob Mutch).}

Australia [20,45]. Panic, poor visibility, and road hazards create accidents that leave people stranded with no protection from smoke, heat, and fire.

By taking responsibility for the protection of their own homes, residents free up important firefighting resources to attack the wildland fire and roads are more open for emergency vehicle ingress and egress. This does not mean that firefighters would not suppress fires on these prepared properties; quite the opposite is true. Firefighters are more likely to enter properties where owners have demonstrated an investment in their own protection, and these property are safer for firefighters to enter and fight fire. But the goal in Painted Rocks is for homeowners to make their properties so safe that intense fire suppression for the defense of their homes is not required.

In summary, the WUI vision in this Montana community is one where people and houses are able to survive fires even when fire services personnel are not available. The Painted Rocks Fire District re-evaluated their reliance on the "evacuation only" policy as a meaningful interface strategy and adopted a different one that offered choices. Once a resident prepares their home, they can either Go Early, or Stay and Defend. As the Fall 2009 Firewise Newsletter of the National Fire Protection Association so clearly indicated: "The growing number of homes within the wildland-urban interface, coupled with the limited resources available to wildland firefighters, suggest that we need to explore new solutions that will make the process safer for all involved when a wildfire threatens lives and property." The responding team at Painted Rocks consists of the effective partnership between fire services and home dwellers. The emergency response theme is comprised of the dual strategy of adequate defendable space and fire resistant homes coupled with the trained and prepared home dweller's motivation to remain on-site and assist with the suppression of spot fires.

The Fall 2009 Firewise Newsletter also emphasized another significant point: "While Prepare/Go Early/Stay and Defend places greater responsibility with 
homeowners, it also offers choices. By learning more about this approach, we can arm ourselves with further options, with each community better able to determine the best approach for its residents."

\section{Sheltering in Place: Rancho Santa Fe in San Diego County, California-A Model for Staying}

Another possible model for future community fire protection is taking place at Rancho Santa Fe in southern California. This program is actively informed by the second author's experience. Information produced by the Rancho Santa Fe Protection District titled "Sheltering in Place During Wildfires - a Modern Approach to Living Safely in a Wildland/Urban Interface Community" describes how this concept will work in five of the newer Rancho Santa Fe communities. Southern California, and in particular, San Diego County, has been reluctant to embrace the $\mathrm{P} / \mathrm{GE} / \mathrm{SD}$ policy.

\subsection{Rancho Santa Fe's Shelter in Place Strategy}

The closest southern California comes to the $\mathrm{P} / \mathrm{GE} / \mathrm{SD}$ model is the concept of Shelter in Place (SIP), which requires residents to leave early in an orderly manner if they can. The only designated SIP developments in southern California at Rancho Santa Fe require Ignition Resistant Homes surrounded by well-maintained Ignition Resistant Landscaping (Figure 2). In the event the resident does not have time to leave before the wildfire arrives the residents are to "Shelter" inside their homes and stay there. In the current SIP model there is, at present, little to no emphasis on taking fire suppression actions outside the home once the fire front passes. Other than the ongoing pre-fire preparation, the SIP resident has a passive role in the defense of his or her property during a wildfire event.

The usual practice throughout southern California is to require evacuations well ahead of the arrival of the wildfire [3]. For instance, in October of 2007 the wildfires in San Diego County resulted in the largest evacuation in California history (over 300,000 people safely evacuated) and the loss of 2,223 homes [25]. Many residents have always defied these orders and stayed behind to protect their property. A few in the past have lost their lives while most have been instrumental in saving their homes and the homes of their absent neighbors. When multiple major wind-driven wildfires are occurring throughout southern California there never will be enough fire engines, trained and equipped firefighters (as in the Canberra, Australia, 2003 fires [36]), or law enforcement personnel to be in every threatened and evacuated neighborhood.

The San Diego County community of Rancho Santa Fe adopted SIP under the forward thinking and guidance of former Fire Chief Erwin Willis and Fire Marshal Cliff Hunter. They implemented the SIP strategy in 2004 in five of the newer Rancho Santa Fe developments. This concept received its first real test during the Firestorms of October 2007. SIP and P/GE/SD both require homeowner education. The big emphasis in both models is on preparedness well ahead of the fire season. When a wildfire occurs, people leave early or stay within the safety of 


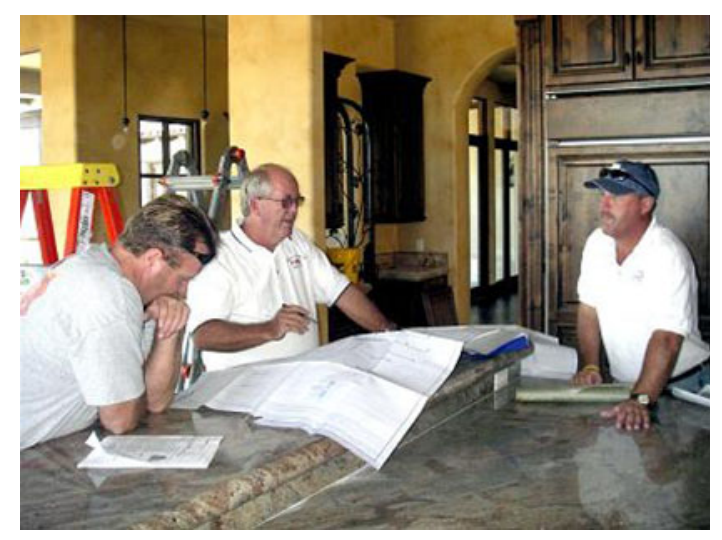

\section{Figure 2. Rancho Santa Fe Fire Marshall Cliff Hunter (Center) does a final house inspection at one of the Rancho Santa Fe's new "Shelter- In-Place"' ignition resistant homes (Photo: Bob Mutch).}

their ignition resistant homes. They are trained not to panic and not to leave at the last possible moment, as this is when citizens can lose their lives and put firefighter's lives needlessly at risk. If your house is ignited and you don't put it out or leave the building, you will be in real trouble.

\subsubsection{Evolution of Shelter in Place at Rancho Santa Fe. How did Rancho Santa} Fe come to embrace the concept of SIP when other southern California wildfire prone communities have not done so? The concept grew out of studies following the 1990 Paint Fire in Santa Barbara, CA, where 438 homes were lost and one resident was killed [46] attempting to evacuate, and the 1991 Oakland Hills Tunnel Fire [47] where 2,475 homes were incinerated and 25 people were killed with 24 of them losing their lives while trying to flee. Erwin Willis, then Fire Marshal with the City of San Luis Obispo, thought "it made no sense that so many residents were losing their lives fleeing structures that we were teaching our firefighters to seek shelter in if trapped by a fire storm" [48]. After reading these studies Willis became convinced that structures and communities could be built that would be safe from wildland fires and residents would not have to risk their lives trying to evacuate. These studies also showed that there was no difference in the survival rates of structures protected by either homeowners or firefighters.

\section{2. "Shelter in Place" at Rancho Santa Fe Tested}

The SIP concept was not tested in a major wildfire until the October 22, 2007, Witch Creek Fire. This occurred during a period of intense Santa Ana winds and several major wildfires had already broken out in southern California, which significantly reduced the number of available ground and air firefighting resources. By Sunday evening and early Monday morning the Witch Creek Fire was burning homes in Ramona, Poway, and Rancho Bernardo and later spread into the SIP communities of Cielo, 4S Ranch, and The Crosby. Because there was so much 
advance warning about the projected path of the Witch Creek Fire, evacuation orders were given early for an orderly evacuation of all of Rancho Santa $\mathrm{Fe}$ through a very effective Reverse 911 system. However, many homeowners in the SIP communities decided to stay, as they had purposely bought homes in a SIP development. During the assessment of home saves and losses, it became readily apparent that no homes were lost in any of the SIP communities. Some residents stayed in The Crosby, some stayed in 4S Ranch (but most left), many stayed in Cielo, and most left in The Bridges. Most residents played a passive role, staying in their homes and taking no direct action before or after the fire front passed. There was an abundance of physical evidence left behind (broken off trees and burned over interior open space areas with native vegetation) that strong winds had severely impacted the SIP Community of 4S Ranch and had indeed pushed the Witch Creek Fire directly through 4 S Ranch.

Although there were no homes lost in any of the five SIP communities, the older parts of Rancho Santa Fe did not fare as well. There were 61 structure losses, the largest structure was $12,000 \mathrm{ft}^{2}\left(1100 \mathrm{~m}^{2}\right)$ in size and the smallest was $400 \mathrm{ft}^{2}\left(37 \mathrm{~m}^{2}\right)$ in size. A few residents in the non-SIP communities decided to stay, but the main water system ran out of water. Inappropriate landscaping was a primary cause in 50 out of the 61 losses with those 50 homes having less than $30 \mathrm{ft}(9 \mathrm{~m})$ of fuel modification from undisturbed wildland fuels and flammable ornamental vegetation. Of the other eleven losses, the landscaping was intact and unburned, yet the structures were burned to the ground due to embers getting into attics via dormer and eave vents. Twelve of the lost homes had wooden siding with bark mulch that went right up to the wooden siding material on the structure. Uncovered trash cans next to structures, bark mulch in contact with the structure, and storage or out buildings located right next to structures all contributed to the loss of homes [49].

All of the San Diego County newspapers highlighted the successful implementation of the SIP concept, which borrows in part from the very successful Australian model of $\mathrm{P} / \mathrm{GE} / \mathrm{SD}$. Hunter was overwhelmed with requests for personal interviews from near and far. No lives had been lost and no homes were lost in the five SIP communities, which was in sharp contrast to the number of homes lost in the rest of San Diego County in October of 2007 and particularly within the City of San Diego.

There were other areas of new homes in the path of the Witch Creek Wildfire located in unincorporated areas well east of Rancho Santa Fe where property owners elected to stay with their homes to defend them before and after the fire front passed through [50]. These residents were strongly encouraged to evacuate well in advance of the main fire front as these areas are not designated as SIP, although most of the homes possessed all of the attributes of a P/GE/SD community. As a case in point, newer homes east of Ramona on Starlight Mountain Road were overrun by the Witch Creek wildfire at approximately 5:00 PM on Sunday evening, October 21, 2007. Several homeowners chose to stay while others evacuated. Those who stayed were instrumental in saving their homes and, in some cases, their neighbors' homes. In one case two new homes that met all updated County of San Diego Wildland Urban Interface Code Requirements survived 
without any intervention. Another brand new home that met all code requirements, with no one there, burned to the ground several hours after the fire front passed through.

Eyewitnesses were clear that homes were not igniting because of direct flame impingement or radiant heat. All of the homes that eventually burned were still standing for several hours after the passage of the fire front. The homes were burning due to the continuous onslaught of windblown embers coming from the burned over area that found their way into the attics, and in one case, embers got beneath a pre-manufactured home. When able-bodied residents are forced to evacuate they give up any chance of saving their own home and the homes of their neighbors. Fire Service personnel are spread too thin to have a firefighter at every home of those residents who were evacuated. No Fire Service personnel were available to assist any of the residents who stayed, or to protect the abandoned homes of those who evacuated their homes on Starlight Mountain Road on October 21, 2007.

There is a big concern in County and City Government circles about potential liability should a homeowner perish in the defense of his or her home. Consider, however, the liability when all residents are forced to leave and the wildfire overruns the evacuation route killing thousands gridlocked on clogged escape routes. On October 26, 2003, the residents of Scripps Ranch, a community within the City of San Diego, received an early morning notice to evacuate. Residents spent two to three hours stuck in their cars in their own neighborhoods trying to get out while the Cedar Fire burned through the Community of Scripps Ranch, resulting in the loss of more than 300 homes. A sudden wind shift would have spelled disaster for thousands of evacuee's (Figure 3). Fortunately that did not happen.

Of the 17 people killed in the 2003 wildfires in San Diego County, most of the fatalities occurred while residents were trying to evacuate [45]. Cova [34] stated that dense developments may discourage consideration of $\mathrm{P} / \mathrm{GE} / \mathrm{SD}$ policies due to the greater possibility of house-to-house ignitions. However, an assessment in Canberra, Australia, identified more than one case where homes in moderately populated areas were saved by residents who stayed and defended even though structures next door were lost due to house-to-house ignition [51]. Cohen [52] indicated a 2-story house separation of $14 \mathrm{~m}(\sim 46 \mathrm{ft})$ or more would not produce ignitions from flame exposure (10 m/ 33 ft for a 1-story house).

Following the latest wildfires in Santa Barbara, Ventura, Los Angeles, and Orange Counties, in November 2008, County Fire Chiefs in Ventura and Orange Counties were conducting meetings in their communities to get a measure of public interest in and acceptance of a "P/GE/SD" strategy and were beginning to develop instructional materials that explain this approach. However, following the south-eastern Australian bushfires of February 2009 this emerging policy has been rethought and retitled, "Ready, Set, Go"-cf. "Prepare, Act, Survive" now used in Australia [see www.cfa.vic.gov.au/, accessed 18 May 2010] — with a renewed emphasis on pre-fire preparation of the home and property, maintaining the home and fire resistant landscaping in a constant state of readiness, but leaving early when the wildfire event occurs. There is no longer an emphasis on Staying and 


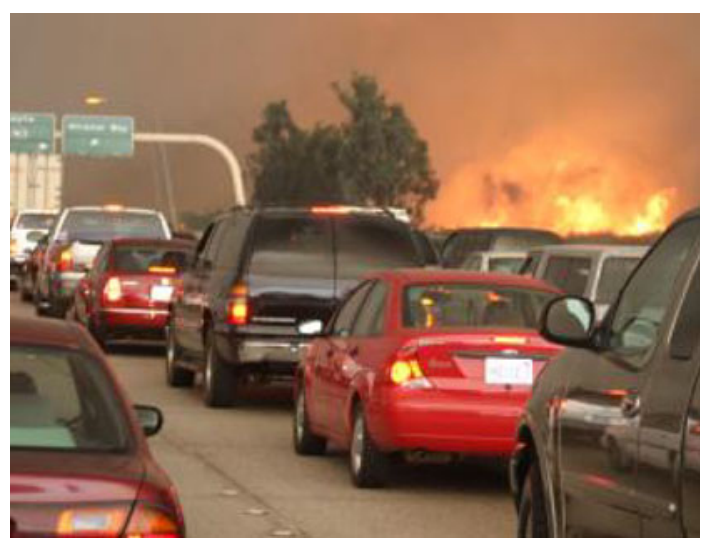

Figure 3. Thousands of evacuees heading north on the I- 15 Freeway, just south of the Miramar Way off ramp. They are cut off with no escape as the Cedar Fire blew across the Freeway early Sunday morning of October 26, 2003, on the Marine Corps Air Station Miramar property. There were just as many stranded vehicles in the south bound lanes that are not shown. A sudden shift in the wind would have burned thousands trapped in their vehicles. In this case, fortunately no one was burned over. Do evacuees present a liability to local governments when mass evacuations are ordered and the evacuees are burned over while trapped on clogged roads and freeways resulting in numerous fatalities? (Photo: Unknown private citizen).

Defending although this new policy acknowledges that some residents will elect to stay behind and that they should be properly equipped and mentally and physically prepared to actively defend their homes if they do decide to Stay and Defend. Once it is safe to do so, residents that stayed behind are advised to thoroughly check their home, yard, roof, attic, etc. for ember fires; and to use a hose or fire extinguisher to suppress any spot fires or smoldering embers. To be considered an SIP community, the entire community must be designed to withstand heat, flames, and embers from an approaching wildfire (see also [4]). This means that every home must share the same ignition-resistant design elements, including a well-maintained fire district approved vegetation management plan. An additional feature is the on-going requirement to continue to maintain all fire resistant landscaping and ignition-resistant housing components in perpetuity.

\section{The Status of Policies Following Black Saturday, February 7, 2009 in Victoria, Australia}

Public policy, scientific advice, and local practice are outcomes of knowledge accumulated from past events and experiences combined with various rationales. The greater the number of events that occur, the wider is the range of circumstances that are experienced and can be scrutinized. With each new event, there is 


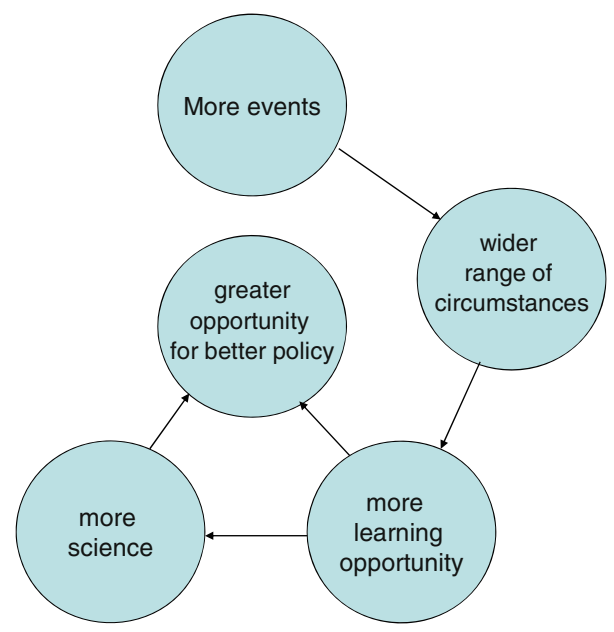

Figure 4. Each new fire incident, or event, provides a new opportunity to reassess accepted practices and revise inferface strategies and tactics based on the additional information. How we respond to interface fires needs to be a continuously evolving process.

increased opportunity for adding to current knowledge and, therefore, gaining greater scientific and public understanding and having a better chance of developing an effective, comprehensive, policy (see Fig. 4).

The many fires of February 2009 in Victoria, Australia, took 173 human lives and burned over 2000 houses [6]. A widespread and long-standing drought provided the background to extreme fire weather. Fuels supporting these fires were widely different across the State with rural pastures, woodlands, and forests all involved. Tall forests of mountain ash (Eucalyptus regnans F. Muell.) found in what are normally high rainfall districts, were close to some hard hit areas such as Marysville: these are singled out here for comment because Wilson and Ferguson [39], after the socially disastrous Ash Wednesday fires of 1983, noted that "The results of this survey suggest that evacuation should not be considered lightly, if at all. While residents of houses surrounded by exceptionally high concentrations of fuel, such as those near mountain ash gullies, might sometimes be wise to evacuate temporarily to safer places nearby, by far the greater proportion of houses offer relatively safe havens during the passage of a fire."

In May 2009, a Royal Commission began formal hearings which examined the stay or go policy among other aspects of the fires [6, pp. 15, 19 and Chap. 7]. This policy had also been examined in the inquiry into the 2003 bushfires in the ACT [21]. In 2001, Australian police commissioners (Queensland aside at that time) accepted the AFAC policy but, in the 2003 Canberra event, there appeared to have been conflicting advice given to residents [21]. What happened in Victoria will be revealed in the Commission's final report in 2010. The interim report indicated the importance of the public understanding what the policy means and communicating this clearly [6, p. 19]. 
In the AFAC policy, the major options are not of concern-stay or evacuate-because these are the only alternatives. It is the detail that is important: What does 'prepare' involve? What does 'leave early' involve? How do these questions apply to different people in different circumstances? Aspects of these questions have been covered above and there are many answers possible, but many of the ramifications have not necessarily been adopted or resolved. Thus, "preparation' may involve fuel management and suppression in whole neighborhoods and include public land, not just one urban lot, so that risk needs to be assessed at an appropriate scale [4]. 'Leaving early' could involve leaving on every "extreme", or now "catastrophic", fire day or on a "total fire ban day' with or without known fire occurrence (see [20]) according to people's perception of risk. Evacuation strategies could differ for different people such as nursing home residents and those with disabilities compared with single young people and families. "Leaving early" also involves the time required to safely reach a known safe haven; and, preparing for the heat, smoke, embers, darkness, and noise of an extreme event. These circumstances are difficult to imagine for those who have not experienced them.

The events of Black Saturday invoked a great deal of public discussion over the influence of climate change on fire potential. While the apparently unprecedented severity of the fire weather during this single event cannot be attributed to climate change with any certainty, it is consistent with predictions of future fire weather [53] and upward trends in the forest fire weather index in Victoria over the somewhat limited decades of measured weather [54]. However, change of some sort is inevitable, whether in population, fuels, weather or technology, and this will potentially affect policy.

\section{Conclusions}

For many years the United States has supported a policy of controlled evacuations administered by local law enforcement officials when WUI areas are threatened by wildfires. When fast moving wildfires occur, emergency evacuation communication to interface residents often arrives so late that numerous individuals are imperiled. As civilian fatalities all too clearly demonstrated in the 1991 Tunnel Fire near Oakland, California, and the 2003 Cedar Fire in San Diego County, California, warnings to evacuate may be late to non-existent.

Recent losses of life and property in the WUI to wildfire in both the United States and Australia continue at high levels. While policies and investments have occurred in the last decade on the public side of the WUI in the United States, corresponding policies and investments on the private side of the WUI are generally lacking. This article summarized two areas in the United States, Painted Rocks in Montana and Rancho Santa Fe in California, which have taken actions to increase their survivability in the WUI. However, other areas with similar characteristics and strategies are rare.

Thus, we can promote close examination of the Australian system of $\mathrm{P} / \mathrm{GE} / \mathrm{SD}$ in the United States, perhaps with modifications in light of the findings of the 
2009 Victorian Bushfires Royal Commission [6]. This fire management strategy actively engages the occupants of the WUI in actions that can reduce losses of life and property [3]. Although annual fuel treatments will not eliminate fire; they will effectively modify fire behavior. Under extreme weather conditions embers will still be produced from adjacent wildland vegetation and these embers will attack the private side of the WUI. If landscaping and structures are not designed and built specifically to resist ember attack, they will be very vulnerable to fire and many of them will be lost. However, if residents accept the fact of inevitable wildfires in the interface and accept the fact of their responsibility to prepare a fire resistant home and landscaping well in advance of subsequent fire seasons, then they will find themselves in the enviable position of having interface choices: either Going really Early ahead of wildfire threats or Staying and Defending their home against the inevitable ember attack.

Residents and officials of the Painted Rocks and Rancho Santa Fe Fire Districts appreciate the fact that reliance on Prepare/Go Early/Stay and Defend places greater responsibility with homeowners. But they also know that there are advantages in having choices when fast moving wildfires threaten. By implementing and successfully testing alternatives to the "evacuation only" model, these two Districts, one in Montana and one in California, have clearly demonstrated meaningful benefits in having options for interface survival - survival that includes the resident as an essential participant.

\section{Acknowledgments}

We gratefully thank Battalion Chief Alan Tresemer, Painted Rocks Fire District, and Alan Taylor, Montana WUI resident and former fire researcher, for their helpful review comments and suggestions.

\section{Open Access}

This article is distributed under the terms of the Creative Commons Attribution Noncommercial License which permits any noncommercial use, distribution, and reproduction in any medium, provided the original author(s) and source are credited.

\section{ADDENDUM}

\section{DEBUNKING MYTHS ABOUT: PREPARE, GO EARLY, OR STAY AND DEFEND (P/GE/SD)}

THE BASIC PREMISE: For people to successfully evacuate early or successfully stay and defend their home, they must first and foremost prepare defensible space around their home, and perhaps in their neighborhood generally, and meet fire resistant building codes, regulations, and requirements. Defensible space and fire 
resistant homes accomplished well ahead of the fire season will permit the effective execution of the other two tactics: Going Early or Staying and Defending. If home and yard have not been prepared to be fire resistant then the only safe tactic is Go Early - really early. If people are unable to cope with fire conditions for various reasons they should also leave very early. However, leaving a well maintained fire resistant property "early", as opposed to leaving an unprepared property "early", does increase the probability that the home will survive and still be there when the homeowner/resident who leaves early is allowed to return. The safety of people is paramount.

MYTH: In a fire all residents will die in their homes.

FACT: Many, if not most, victims perish while attempting to evacuate, usually going at the very last minute.

MYTH: Homes in the interface generally are ignited by the adjacent flames of a crown fire.

FACT: As stated above, homes in the interface generally are ignited by small wind-blown embers. Ignited homes can be lost hours after the main fire front has passed. If someone is present, these small ember ignitions can be easily suppressed. If no one is present, a home may easily burn to the ground much later.

MYTH: Homes threatened by wildfire cannot provide a safe refuge for people.

FACT: Homes repeatedly have provided a safe refuge for both firefighters and residents, shielding them from the radiant heat and dense smoke that accompany wildfires. Homes may eventually ignite, but by that time it is usually safe for people to go back outside because the main front has passed. However, people have died in poorly maintained and unsafe homes.

MYTH: People seeking refuge in a home threatened by wildfire will be asphyxiated.

FACT: People, both residents and firefighters, often have been effectively sheltered by a home that blocks radiant heat and smoke.

MYTH: When wildfires threaten homes during periods of extreme fire danger, the Fire Service will save them.

FACT: Wildfires that start during periods of very high to extreme fire danger will quickly overwhelm Fire Services, because they will not be able to keep up with all the new ignitions in the interface. It must be understood that there are hundreds or thousands of engines ('tankers') and tens of thousands to hundreds of thousands of homes in the interface. There will not be an engine at every home. The good news is that if people prepare well for defensible space around their home and have a fire resistant home in a well-prepared neighborhood, their property may survive a wildfire even when the Fire Services are not available.

MYTH: Some people are saying that anyone can stay inside their home and ride out the fire storm after preparing home and property to be fire resistant. 
FACT: Only able bodied adults, properly prepared both physically and mentally, should consider staying behind to defend their well prepared fire resistant homes. Children, infirm people, and elderly residents should leave early, well before the arrival of any wind-blown embers or flames. Those who stay need to know what 'well prepared' means in their circumstances.

MYTH: Some people are suggesting that the strategy of Prepare/Go Early/Stay and Defend can be applied in all communities.

FACT: The houses that have been burning in Wildland Urban Interface fires in the United States were not in planned communities with adequate individual fuel treatment zones (homes in newer fire planned communities are not burning). Older communities, however, can be retrofitted and there is grant money in the United States available to make structures ignition resistant, but this requires every homeowner/resident to agree to and actually modify their structure to updated fire codes.

MYTH: Prepare/Go Early/Stay and Defend is being brought forward as a planning strategy to be used where there is only one way in and one way out and timely evacuation of a proposed planned community is not possible.

FACT: Prepare/Go Early/Stay and Defend is not used in lieu of not having adequate evacuation routes. Prepare/Go Early/Stay and Defend cannot work as a viable strategy without safe evacuation routes.

MYTH: Prepare/Go Early/Stay and Defend applies to all situations.

FACT: The circumstances of fires and communities now and in a changing world vary widely. There is no guarantee that staying and sheltering or staying and defending will guarantee your survival under all possible circumstances.

\section{References}

1. Rogers MJ, Halstead D, Spitzer HA, Smalley JC (2005) Protecting life and property from wildfire. National Fire Protection Association (NFPA No. WILD05), 291 pp; plus appendices

2. Alavalapaiti JR, Carter DC, Newman DH (2005) Wildland-urban interface: challenges and opportunities. For Policy Econ 7:705-708

3. Stephens SL, Adams M, Handmer J, Kearns F, Leicester B, Leonard J, Moritz M (2009) Urban-wildland fires: how California and other regions of the U.S. can learn from Australia. Environ Res Lett 4:014010

4. Gill AM, Stephens SL (2009) Scientific and social challenges for the management of fire-prone wildland-urban interfaces. Environ Res Lett 4:034014

5. Blackwell JA, Tuttle A (2003) California fire siege 2003. The story. California Department of Forestry and Fire Protection, Sacramento, CA

6. Teague B, McLeod R, Pascoe S (2009) 2009 Victorian Bushfires Royal Commission interim report. Government Printer, Victoria, $360 \mathrm{p}$ 
7. Alexander ME, Mutch RW, Davis KM (2007) Wildland fires: dangers and survival. In: Auerbach PS (ed) Wilderness medicine, 5th edn. Mosby-Elsevier, Philadelphia, PA, pp 286-335

8. Mutch RW, Lee B, Perkins JH (1998) Public policies affecting forest fires in the Americas and the Caribbean. In: FAO meeting on public policies affecting forest fires, Rome, 28-30 October 1998, pp 65-108

9. Xanthopoulos G (2007) The fires in Greece of August 24-28, 2007. Published by www.iawfonline.org. www.fire.uni-freiburg.de/media/2007/2008/news_20070829_gr.htm. Accessed 21 April 2010

10. De Ronde C, Goldammer JG (2001) Fire situation in South Africa. Int For Fire News 25:105-110

11. Lifu S, Xiaorui T (2002) Fire situation in China. Int For Fire News 26:9-14

12. Martin RE (1991) Vegetation aspects of the wildland/urban fire problem Integrating Research on Hazards in Fire-Prone Environments. In: Daniel TC, Ferguson IS (eds) Proceedings of the US-Australia Workshop Melbourne 1989. US Man and the Biosphere Program, Washington, DC, pp 27-31

13. Fried JS, Winter GJ, Gilles JK (1999) Assessing the benefits of reducing fire risk in the wildland-urban interface: a contingent valuation approach. Int J Wildland Fire 9:9-20

14. Cohen JD (2000) Preventing disaster: home ignitability in the wildland-urban interface. J For 98:15-21

15. Leonard JE, Leicester RH, Bowditch PA (2003) Bushfire catastrophe: Myth or fact? In: Britton NR (ed) Proceedings of the conference on Catastrophic Risks and Insurability, pp 1-9

16. Wang H (2006) Ember attack: its role in the destruction of houses during ACT bushfire in 2003. In: Tran C (ed) Life in a fire-prone environment: translating science into practice. Bushfire Conf. 2006, Brisbane, June 2006

17. McCaffrey SM (2004) Thinking of wildfire as a natural hazard. Nat Resour J 17:509516

18. Mileti DS (1999) Disasters by design: a reassessment of natural hazards in the United States. Joseph Henry Press, Washington, DC

19. Franklin JF, Agee JA (2003) Forging a science-based national forest fire policy. Issues Sci Technol 20:59-66

20. Handmer J, Tibbets A (2005) Is staying at home the safest option during bushfires? Historical evidence for an Australian approach. Environ Hazards 6:81-91

21. McLeod R (2003) Inquiry into the operational response of the January 2003 Bushfires in the ACT. Australian Capital Territory, Canberra. www.cmd.act.gov.au/_data/assets/ pdf_file/0008/113939/McLeodInquiry.pdf. Accessed 31 May 2010

22. Radeloff VC, Hammer RB, Stewart SI, Fried JS, Holcomb SS, McKeefry JF (2005) The wildland-urban interface in the United States. Ecol Appl 15:799-805

23. Bosworth D (2003) Is America on track toward sustainable forests? Keynote Presentation, Society of American Foresters Annual Convention, October 26, 2003

24. Bengston DN, Potts RS, Fan DP, Goetz EG (2005) An analysis of public discourse about urban sprawl in the United States: monitoring concern about a major threat to forests. For Policy Econ 7:745-756

25. McCaffrey SM, Rhodes A (2009) Public response to wildfire: is the Australian "Stay and Defend or Leave Early" approach an option for wildfire management in the United States?. J For 107(1):9-14

26. Nelson KC, Monroe MC, Johnson JF, Bowers A (2004) Living with fire: homeowner assessment of landscape values and defensible space in Minnesota and Florida, USA. Int J Wildland Fire 13:413-425 
27. Forest Service (2008) Forest service manual. Title 5100: Fire management, sections 5137 and 5137.02. Accessed at http://www.fs.fed.us/cgibin/Directives/get_dirs/fsm?5100

28. Stephens SL, Ruth LW (2005) Federal forest fire policy in the United States. Ecol Appl 15:532-542

29. Agee JK, Skinner CN (2005) Basic principles of forest fuel reduction treatments. For Ecol Manag 211:83-96

30. USDA-USDI (2000) A report to the President in response to the wildfires of 2000. USDA and USDI. www.fireplan.gov $\backslash$ president.cfm

31. WGA (2001) A collaborative approach for reducing wildland fire risk to communities and the environment: 10-year comprehensive strategy. Western Governors' Association. www.westgov.org/wga/initiatives/fire/final_fire_rpt.pdf. Accessed 2005

32. HFRA (2003) Healthy forest restoration act. H.R. 1904. United States Congress, Washington, DC. Available on world wide web at http://www.healthyforests.gov/. Accessed 8 December 2005

33. Reams MA, Haines TK, Renner CR, Wascom MW, Kungre H (2005) Goals, obstacles and effective strategies of wildfire mitigation programs in the wildland-urban interface. For Policy Econ 7:818-826

34. Cova TJ (2005) Public safety in the urban-wildland interface: should fire-prone communities have a maximum occupancy? Nat Hazards Rev 6:99-108

35. Chen K, McAneney J (2005) The bushfire threat in urban areas. Aust Sci 26(1):14-16

36. Gill AM (2005) Landscape fires as social disasters: an overview of 'the bushfire problem'. Environ Hazards 6:65-80

37. Boura J (1998) Community Fireguard: creating partnerships with the community to minimise the impact of bushfire. Aust J Emerg Manag 13:59-64

38. Cohen J (2008) The wildland-urban interface fire problem: a consequence of the fire exclusion paradigm. For Hist Today Fall:20-26

39. Wilson AAG, Ferguson I (1984) Flight or flee? A case study of the Mount Macedon bushfire. Aust For 47:230-236

40. ACT Emergency Services Agency (2004) Bushfires in the Bush Capital. A Guide for the ACT.

www.esa.act.gov.au/ESAWebsite/content_esa/community_education/

bushfires_in_the_bush_capital/bushfires_in_the_bush_capital.html

41. Haynes $\bar{K}$, Tibbets $\bar{A}$, Coates L, Ganewatta G, Handmer J, McAneney J (2008) 100 years of Australian civilian bushfire fatalities: exploring the trends in relation to the 'stay or go policy'. A Report for the Bushfire CRC, $30 \mathrm{pp}$

42. Blanchi R, Leonard J, Maughan D (2004) Towards new information tools for understanding bushfire risk at the urban interface. In: Earth wind and fire-Bushfire 2004 conference, Adelaide

43. Leonard JE, Blanchi R, Leicester RH (2004) On the development of a risk-model for bushfire attack on housing. In: Risk 2004 national conference, Melbourne, 7-10 November 2004

44. Standards Australia AS 3959-2009. Construction of buildings in Bushfire Prone areas. See http://webstore.ansi.org/RecordDetail.aspx?sku = AS + 3959-2009

45. Mutch RW (2007) FACES: the story of the victims of southern California's 2003 fire siege. Wildland Fire Lessons Learned Center, 103 pp

46. Foote EI (1994) Structural survival on the 1990 Santa Barbara paint fire: a retrospective study of urban-wildland interface fire hazard mitigation factors Thesis (MS in Wildland Resource Science) University of California, Berkeley, p 294 
47. Gordon DA (2000) Structure survival in the urban/wildland interface: a logistic regression analysis of the 1991 Oakland/Berkeley tunnel fire. Thesis (MS in Wildland Resource Science), University of California, Berkeley

48. Willis EL (2009) Origin of the Rancho Santa Fe "Shelter in Place Communities", pp 1-2, an unpublished paper

49. Hunter C (2008) Personal Interview with Rancho Santa Fe Fire Marshal, Cliff Hunter by Michael J. Rogers on 12/03/2008

50. Rogers MJ (2008) Updated analysis of homes that survived the witch creek fire of October 21, 2007, pp 1-32, Internal Paper

51. Leonard JE, Blanchi R (2005) Investigation of bushfire attack mechanisms involved in house loss in the ACT Bushfire 2003, Bushfire CRC report. CSIRO Manufacturing \& Infrastructure Technology, Highett, VIC

52. Cohen JD (1995) Structure ignition assessment model (SIAM). In: Proceedings of the Biswell symposium: fire issues and solutions in urban interface and wildland ecosystems, Walnut Creek, CA, 15-17 Feb 1994. Gen. Tech. Rep. PSW-158. USDA Forest Service, Albany, CA, pp 85-92

53. Hennessy K, Lucas C, Nicholls N, Bathols J, Suppiah R, Ricketts J (2005) Climate change impacts on fire weather in south-east Australia. CSIRO Australia, Canberra

54. Esplin B, Gill AM, Enright N (2003) Report of the Inquiry into the 2002-2003 Victorian Bushfires. State Government of Victoria, Melbourne, 370 p. See www.dpc. vic.gov.au 